\section{Enhancement of Seed Germination in Common Carpetgrass and Centipedegrass Seed}

\author{
Edward W. Bush' 1 , Paul Wilson², Dennis P. Shepard ${ }^{3}$, and \\ Gloria McClure ${ }^{4}$ \\ Department of Horticulture, Louisiana State University Agricultural Center, \\ 137 J.C. Miller Hall, Baton Rouge, LA 70803
}

Additional index words. Axonopus affinis, Eremochloa ophuiroides, seed germination, priming, potassium nitrate

\begin{abstract}
Priming or presoaking seed of common carpetgrass (Axonopus affinis Chase) and centipedegrass [Eremochloa ophiuroides Munro. (Kunz)] increased germination percentage and decreased mean time of germination (MTG) at 20, 25, and $30{ }^{\circ} \mathrm{C}$. The effect of presoaking and priming was dependent on grass species and temperature. The optimum seed germination temperature for both of these warm-season species was $30^{\circ} \mathrm{C}$. Maximum effect on common carpetgrass or centipedegrass seeds was achieved by priming in $2 \%$ $\mathrm{KNO}_{3}$; higher concentrations did not improve germination percentage or MTG, and $4 \%$ was in some cases detrimental. Germination was higher and MTG lower at 20 and $30{ }^{\circ} \mathrm{C}$ than at $15^{\circ} \mathrm{C}$. Presoaking common carpetgrass and centipedegrass seeds was the most efficient seed enhancement treatment for germination at $30{ }^{\circ} \mathrm{C}$.
\end{abstract}

Viable seed and a suitable environment are necessary for rapid establishment of turfgrass sod. Centipedegrass and common carpetgrass, both warm-season turfgrasses, are frequently established by sowing monostands or using seed mixtures. Common carpetgrass is frequently used as a companion grass with centipedegrass to reduce establishment time. Establishing warm-season grasses from seed during the early spring months when soil temperatures are cold can be challenging. Seed priming prior to planting has been used extensively with other grasses to accelerate germination time, break dormancy, and improve germination percentage and uniformity at suboptimum temperatures. Seed priming is a controlled-hydration treatment in which seeds are exposed to an external water potential sufficiently low to prevent radical protrusion, and yet stimulate physiological and biochemical

Received for publication 27 July 1998. Accepted for publication $16 \mathrm{Feb}$. 1999. Approved for publication by the director of the Louisiana Agricultural Experiment Station as manuscript number 98-28-0211. This research was supported by funds from State and matching funds allocated to the Louisiana State Univ. Agricultural Center. The cost of publishing this paper was defrayed in part by the payment of page charges. Under postal regulations, this paper therefore must be hereby marked advertisement solely to indicate this fact.

${ }^{1}$ Assistant Professor. To whom reprint requests should be addressed. E-mail address: ebush@ agctr.lsu.edu ${ }^{2}$ Professor. E-mail address: pwilson@ agctr.lsu.edu ${ }^{3}$ Former Assistant Professor. Present address: Novartis Crop Protection Inc., 11561 Hemlock Drive, Overland Park, KS 66210.

${ }^{4}$ Research Assistant. Present address: Department of Plant Pathology and Crop Physiology, Louisiana State Univ. Agricultural Center, 302 Life Sciences Bldg., Baton Rouge, LA 70803. activities. Potassium nitrate $\left(\mathrm{KNO}_{3}\right)$ has been used successfully in many horticultural crops to control seed hydration (Bradford, 1986; Heydecker and Coolbear, 1977). Germination rate can be increased at temperatures considered suboptimal for germination (Brede and Brede, 1989; Hardegree, 1994; Murray, 1990). Improved seed germination may be the result of physiological changes occurring during imbibition at low-germination temperatures (McClure, 1995).

Priming with $\mathrm{KNO}_{3}$ significantly advanced the rate of germination of perennial ryegrass (Lolium perenne L.), browntop [Agrostis capillaris L. (Pers.)], and Kentucky bluegrass (Poa pratensis L.) (Lush and Birkenhead, 1987). Maguire and Steen (1971) reported that $\mathrm{KNO}_{3}$ accelerated the rate of seed germination in Kentucky bluegrass. Additionally, priming perennial ryegrass seed with polyethylene glycol (PEG) at -1.0 MPa increased germination by 35\% (Danneberger et al., 1992). Adegbuyi et al. (1981) determined that priming seeds of cool-season grass species sheep fescue (Festuca ovina L.), ryegrass, and rough bluegrass (Poa trivialis L.) with priming salts $(-1.0$ to $-1.4 \mathrm{MPa})$ significantly increased the speed of germination at suboptimum temperatures. Hardegree (1994) demonstrated that priming Great Plains native perennial grass seeds $(-1.0$ to $-2.5 \mathrm{MPa})$ reduced mean time of germination (MTG) by 4 to $8 \mathrm{~d}$. Priming wheat (Triticum durum L.) and wild oat (Avena fatua L.) seeds at $-1.0 \mathrm{MPa}$ accelerated germination, thereby improving seedling competitiveness against weeds (Akalehiywot and Bewley, 1977).

Although seed priming has been used extensively to improve germination of cool-season turfgrass, priming of warm-season turfgrass has not been thoroughly investigated. Presoak- ing buffalograss [Buchloë dactyloides (Nutt.) Engelm.] burrs in water significantly increased MTG by 1 week (Fry et al., 1993), and soaking centipedegrass seeds in water increased germination by $7 \%$ (Walker, 1976). Toole and Toole (1939) increased common carpetgrass seed germination rate by moistening germination paper with a $0.2 \% \mathrm{KNO}_{3}$ solution. Recommendations for germinating common carpetgrass include moistening germination filter paper with $0.2 \% \mathrm{KNO}_{3}$, and exposing seeds to at least $8 \mathrm{~h}$ of cool-white fluorescent light (11 to 19 $\left.\mu \mathrm{mol} \cdot \mathrm{m}^{-2} \cdot \mathrm{s}^{-1}\right)$, and alternating temperatures $15 /$ $25^{\circ} \mathrm{C}$ (Association of Official Seed Analysts, 1994). These recommendations for common carpetgrass seed are not referenced, and no seed testing recommendations are given for centipedegrass by the Association of Official Seed Analysts (1994).

We tested the hypothesis that priming and presoaking would improve common carpetgrass and centipedegrass seed germination at suboptimum $\left(<30^{\circ} \mathrm{C}\right)$ temperatures.

\section{Materials and Methods}

We used two grass species (common carpetgrass and centipedegrass), four isothermic germination temperatures $(15,20,25$, and $30{ }^{\circ} \mathrm{C}$ ), and six seed treatments [0\% (distilled water); $1 \%, 2 \%, 3 \%$, and $4 \% \mathrm{KNO}_{3}$ solutions; and an untreated control]. These concentrations of $\mathrm{KNO}_{3}$ provided osmotic pressure of -0.5 , $-0.9,-1.3$, and $-1.7 \mathrm{~Pa}$, respectively. The two grass species and four germination temperatures were evaluated separately. A thermogradient table (Scientific Systems Corp., Baton Rouge, La.), with four isothermic temperature lanes calibrated at $15,20,25$, or $30{ }^{\circ} \mathrm{C}$, was sectioned into two blocks. A block consisted of six seed treatments in petri dishes randomized within each temperature lane. Cool-white fluorescent lights (19 $\mu \mathrm{mol} \cdot \mathrm{m}^{-2} \cdot \mathrm{s}^{-1}$ ) provided $14 \mathrm{~h}$ of daily illumination. The experiment was repeated twice over time for each grass species and germination temperature to establish four blocks.

Centipedegrass (Lot \# 95/05; Patten Seed, Lakeland, Ga.) and common carpetgrass (Lot \# U4/410; Pennington Seed, Hammond, La.) seeds were soaked for $48 \mathrm{~h}$ in aerated distilled water $(-0.06 \mathrm{MPa})$ or primed for $48 \mathrm{~h}$ with $\mathrm{KNO}_{3}$ solutions maintained at $25^{\circ} \mathrm{C}$. The osmolality of priming solutions (vapor pressure osmometer; Wescor, Logan, Utah) was measured prior to and following the 48-h treatment period. Each solution was aerated using a standard aquarium pump. Following treatments, seeds were rinsed with copious amounts of water, transferred to paper towels, and airdried for $1 \mathrm{~h}$. Fifty seeds of each seed treatment were placed into separately labeled $6.0-\mathrm{cm}$ diameter petri dishes lined with Whatman \#42 filter papers moistened with $2 \mathrm{~mL}$ of distilled water. A control treatment (untreated seed) was also included. Seeds were misted with distilled water daily as needed to prevent desiccation.

Germination counts (radicle protrusion) were taken daily for $21 \mathrm{~d}$ and germinated seed discarded. MTG and germination percentage 
Table 1. Effects of soaking and/or priming seeds of common carpetgrass and centipedegrass on germination during $21 \mathrm{~d}$ incubation at $15,20,25$, or $30{ }^{\circ} \mathrm{C}$.

\begin{tabular}{|c|c|c|c|c|c|c|c|c|c|}
\hline \multicolumn{2}{|l|}{ Treatment } & \multicolumn{4}{|c|}{ Germination $(\%)$} & \multicolumn{4}{|c|}{ Mean time of germination (days) } \\
\hline $\mathrm{KNO}_{3}$ priming solution $(\%)$ & $\Psi(\mathrm{MPa})$ & $15^{\circ} \mathrm{C}$ & $20^{\circ} \mathrm{C}$ & $25^{\circ} \mathrm{C}$ & $30^{\circ} \mathrm{C}$ & $15^{\circ} \mathrm{C}$ & $20^{\circ} \mathrm{C}$ & $25^{\circ} \mathrm{C}$ & $30^{\circ} \mathrm{C}$ \\
\hline \multicolumn{10}{|c|}{ Carpetgrass } \\
\hline 0 (Presoaking) & -0.06 & $4.1 \mathrm{a}$ & $64.6 \mathrm{ab}^{\mathrm{z}}$ & $96.0 \mathrm{a}$ & $97.6 \mathrm{a}$ & $13.6 \mathrm{a}$ & $8.3 \mathrm{~b}$ & $3.2 \mathrm{c}$ & $2.1 \mathrm{c}$ \\
\hline 1 & -0.5 & $5.5 \mathrm{a}$ & $65.6 \mathrm{ab}$ & $98.5 \mathrm{a}$ & $98.1 \mathrm{a}$ & $15.0 \mathrm{a}$ & $7.5 \mathrm{~b}$ & $3.3 \mathrm{c}$ & $2.0 \mathrm{c}$ \\
\hline 2 & -0.9 & $6.1 \mathrm{a}$ & $83.7 \mathrm{a}$ & $99.0 \mathrm{a}$ & $97.0 \mathrm{a}$ & $14.6 \mathrm{a}$ & $7.2 \mathrm{~b}$ & $3.6 \mathrm{bc}$ & $2.1 \mathrm{c}$ \\
\hline 3 & -1.3 & $2.1 \mathrm{a}$ & $85.6 \mathrm{a}$ & $96.9 \mathrm{a}$ & $99.5 \mathrm{a}$ & $12.5 \mathrm{a}$ & $7.1 \mathrm{~b}$ & $3.4 \mathrm{c}$ & $2.2 \mathrm{c}$ \\
\hline 4 & -1.7 & $4.7 \mathrm{a}$ & $82.7 \mathrm{a}$ & $96.6 \mathrm{a}$ & $95.9 \mathrm{a}$ & $15.3 \mathrm{a}$ & $8.0 \mathrm{~b}$ & $4.0 \mathrm{~b}$ & $2.9 \mathrm{~b}$ \\
\hline Control & (untreated) & $6.0 \mathrm{a}$ & $49.3 \mathrm{~b}$ & $87.9 \mathrm{~b}$ & $95.1 \mathrm{a}$ & $12.3 \mathrm{a}$ & $10.2 \mathrm{a}$ & $5.6 \mathrm{a}$ & $4.4 \mathrm{a}$ \\
\hline Linear & & NS & $*$ & NS & NS & NS & NS & NS & NS \\
\hline Nonlinear & & NS & NS & NS & NS & NS & NS & NS & NS \\
\hline \multicolumn{10}{|c|}{ Centipedegrass } \\
\hline 0 (Presoaking) & -0.06 & $11.0 \mathrm{a}$ & $36.6 \mathrm{a}$ & $33.5 \mathrm{~b}$ & $87.5 \mathrm{a}$ & $14.3 \mathrm{a}$ & $9.3 \mathrm{bc}$ & $5.7 \mathrm{ab}$ & $2.8 \mathrm{~b}$ \\
\hline 1 & -0.5 & $12.1 \mathrm{a}$ & $32.8 \mathrm{a}$ & $35.0 \mathrm{~b}$ & $72.0 \mathrm{~b}$ & $13.4 \mathrm{a}$ & $8.0 \mathrm{c}$ & $4.6 \mathrm{~b}$ & $3.2 \mathrm{~b}$ \\
\hline 2 & -0.9 & $6.0 \mathrm{a}$ & $29.0 \mathrm{a}$ & $58.3 \mathrm{a}$ & $73.6 \mathrm{~b}$ & $16.7 \mathrm{a}$ & $9.4 \mathrm{bc}$ & $5.7 \mathrm{ab}$ & $3.6 \mathrm{~b}$ \\
\hline 3 & -1.3 & $4.0 \mathrm{a}$ & $26.7 \mathrm{a}$ & $36.4 \mathrm{~b}$ & $62.0 \mathrm{bc}$ & $17.0 \mathrm{a}$ & $10.3 \mathrm{ab}$ & $6.4 \mathrm{ab}$ & $3.1 \mathrm{~b}$ \\
\hline 4 & -1.7 & $5.0 \mathrm{a}$ & $21.0 \mathrm{a}$ & $30.0 \mathrm{~b}$ & $57.0 \mathrm{c}$ & $14.6 \mathrm{a}$ & $11.0 \mathrm{a}$ & $5.4 \mathrm{~b}$ & $3.1 \mathrm{~b}$ \\
\hline Control & (untreated) & $5.0 \mathrm{a}$ & $22.2 \mathrm{a}$ & $34.5 \mathrm{~b}$ & $33.0 \mathrm{~d}$ & $15.0 \mathrm{a}$ & $11.4 \mathrm{a}$ & $8.6 \mathrm{a}$ & $5.5 \mathrm{a}$ \\
\hline Linear & & NS & NS & NS & NS & NS & NS & NS & NS \\
\hline Nonlinear & & NS & NS & NS & NS & NS & NS & NS & NS \\
\hline
\end{tabular}

${ }^{2}$ Mean separation within columns and species by Duncan's new multiple range test $(P \leq 0.05)$.

Ns, ${ }^{*}, * *$ Nonsignificant or significant at $P \leq 0.05$ and 0.01 , respectively, within columns and species.

of primed seeds were calculated and compared with those of nonprimed seeds (control). MTG was calculated as follows: $\mathrm{MTG}=(\Sigma T i \mathrm{Ni}) /$ $G$, where $T i$ is the day of germination, $N i$ is the number of seeds germinating on $T i$, and $G$ is the total number of germinated seeds (Hartmann et al., 1990). A tetrazolium test was used to determine the viability of nongerminated seeds (Association of Official Seed Analysts, 1994). Seed germination was calculated based as the sum of percentages of viable seeds and germinated seeds.

The experimental design used for both grass species and temperature was a randomized complete-block with four replications. A general linear model was performed separately on each grass species and germination temperature, using the SAS statistical package (SAS Inst., 1991). Means were separated using Duncan's new multiple range test at $P \leq 0.05$.

\section{Results and Discussion}

Data for carpetgrass and centipedegrass data were evaluated separately. There were no significant differences over time for either species at $P \leq 0.05$. Therefore, the experiment was analyzed as a randomized complete-block design.

Common carpetgrass. Presoaking in distilled water did not significantly improve germination at $15^{\circ} \mathrm{C}$, but affected germination at higher temperatures (Table 1). Presoaking hastened germination significantly at $20^{\circ} \mathrm{C}$, but did not increase germination percentage. Presoaking improved germination percentage at $25{ }^{\circ} \mathrm{C}$ but not at $30{ }^{\circ} \mathrm{C}$ (Table 1), and reduced MTG at both temperatures by $\approx 2 \mathrm{~d}$.

Priming in $\mathrm{KNO}_{3}$ had a slight effect on germination, but did not reduce MTG at $15^{\circ} \mathrm{C}$ (Table 1). The relationship between $\mathrm{KNO}_{3}$ concentration and germination at $20^{\circ} \mathrm{C}$ was linear. Mean time of germination was significantly decreased by $\approx 2 \mathrm{~d}$ in comparison to control seeds (Table 1). Priming with $\mathrm{KNO}_{3}$
$(1 \%, 2 \%, 3 \%$, and $4 \%)$ and exposing to $25^{\circ} \mathrm{C}$ significantly increased germination percentage and decreased MTG. Although germination percentage at $30^{\circ} \mathrm{C}$ was not improved by priming, $\mathrm{MTG}$ was reduced by $\approx 2 \mathrm{~d}$ relative to the control.

Centipedegrass. There were no benefits to presoaking seed germinated at 15 or $25{ }^{\circ} \mathrm{C}$ (Table 1). Presoaking did not increase germination percentage at $20{ }^{\circ} \mathrm{C}$, but accelerated MTG by $\approx 2 \mathrm{~d}$. The highest germination percentage $(87.5 \%)$ resulted from presoaking seed and germinating at $30{ }^{\circ} \mathrm{C}$; MTG was also reduced $\geq 2.5 \mathrm{~d}$.

Germination percentage at $15^{\circ} \mathrm{C}$ decreased linearly as $\mathrm{KNO}_{3}$ concentration increased (Table 1), but MTG was not significantly reduced by priming. Priming did not increase germination percentage at $20^{\circ} \mathrm{C}$, but MTG increased linearly with increasing $\mathrm{KNO}_{3}$ concentration. Priming in $2 \% \mathrm{KNO}_{3}$ significantly increased germination by $23 \%$ at $25^{\circ} \mathrm{C}$. Mean time of germination was reduced by $3 \mathrm{~d}$ for seeds primed in either $1 \%$ or $4 \% \mathrm{KNO}_{3}$. Priming increased germination percentage at $30^{\circ} \mathrm{C}$ and reduced $\mathrm{MTG} \approx 2 \mathrm{~d}$.

\section{Conclusions}

Presoaking and priming may be of little value at $15^{\circ} \mathrm{C}$, but priming common carpetgrass and centipedegrass seeds has potential for improving seed germination or reducing MTG at germination temperatures between 20 and $30^{\circ} \mathrm{C}$. Currently, there is no commercial source of primed or presoaked seed of carpetgrass or centipedegrass. However, the results of this study indicate that MTG of both species could be reduced by presoaking and/or priming.

\section{Literature Cited}

Adegbuyi, E., S.R. Cooper, and R. Don. 1981. Osmotic priming of some herbage grass seed using polyethylene glycol (PEG). Seed Sci. Technol. 9:867-878.

Akalehiywot, T. and J.D. Bewley. 1977. Promotion and synchronization of cereal grain germination by osmotic pretreatment with polyethylene glycol. J. Agr. Sci. 89:503-506.

Association of Official Seed Analysts. 1994. Rules for testing seeds. J. Seed Technol. 16:1-113.

Bradford, K.J. 1986. Manipulation of seed water relations via osmotic priming to improve germination under stress conditions. HortScience 21:1105-1112.

Brede, J. and A.D. Brede. 1989. Seed priming. Grounds Maintenance 4:42, 46, 48.

Danneberger, T.K., M.B. McDonald, Jr., C.A. Geron, and P. Kumari. 1992. Rate of germination and seedling growth of perennial ryegrass seed following osmoconditioning. HortScience 27:28-30.

Delouche, J.C. 1961. Effect of gibberellin and light on germination of centipedegrass seed (Eremochloa ophiuroides). Proc. Offic. Seed Analysts 51:147-150.

Fry, J.D., W. Upham, and L. Leuthold. 1993. Seeding month and seed soaking affect buffalograss establishment. HortScience 28:902-903.

Hardegree, S.P. 1994. Matric priming increases germination rate of Great Basin native perennial grasses. Agron. J. 86:289-293.

Hartmann, H.T., D.E. Kester, and F.D. Davies, Jr. 1990. Plant propagation: Principles and practices, 5th ed. Prentice Hall, Englewood Cliffs, N.J.

Heydecker, W. and P. Coolbear. 1977. Seed treatments for improved performance: Survey and attempted prognosis. Seed Sci. Technol. 5:353425.

Lush, W.M. and J.A. Birkenhead. 1987. Establishment of turf using advanced 'pregerminated' seeds. Austral. J. Expt. Agr. 27:323-337.

Maguire, J.D. and K.M. Steen. 1971. Effects of potassium nitrate on germination and respiration of dormant and nondormant Kentucky bluegrass (Poa pratensis L.) seed. Crop Sci. 11:48-50.

McClure, G. 1995. Sweet corn seed reserve changes during imbibition in relation to germination at low temperature. MS Thesis, Louisiana State Univ., Baton Rouge.

Murray, G. 1990. Priming sweet corn seed to improve emergence under cool conditions. HortScience 25:231.

SAS Institute. 1991. SAS users guide. SAS Inst. Cary, N.C

Toole, E.H. and V.K. Toole. 1939. Notes: Germination of carpetgrass seed. Amer. Soc. Agron. 31:566-567.

Walker, J.T. 1976. Centipedegrass seed treatments and light-temperature effects on germination. Plant Dis. Rptr. 60:393-397. 